\title{
Analisis Strategi Manajemen Pancasila Untuk Globalisasi
}

\section{"The Analysis of Pancasila Strategic Management for Globalization"}

Oleh:

\author{
Eko Riwayadi ${ }^{1}$; Bunga Tri Amanda ${ }^{2}$; Nani Juwantini ${ }^{3}$ \\ Program Magister Manajemen Universitas Pelita Bangsa123 \\ eriwayadi@gmail.com; bunga.triamanda@gmail.com²; nanijuwantini0812@gmail.com ${ }^{3}$
}

\begin{tabular}{llll}
\hline Submit: XXX & Review: XXX & Accept: $X X X$ & Publish: $X X X$
\end{tabular}

\begin{abstract}
ABSTRAK
Pancasila sebagai dasar negara Republik Indonesia mempunyai butir-butir yang terkandung di dalamnya dan itu adalah Strategi Manajemen yang akan semakin terkenal menjadi Strategi Manajemen Pancasila untuk menjalankan kehidupan bagi bangsa Indonesia. Kehidupan itu mencakup semua sektor baik ekonomi, politik, sosial dan budaya. Banyak yang kurang memahami peranan dan kegunaan Strategi Manajemen Pancasila terutama dalam kancah globalisasi. Banyak yang beranggapan bahwa Indonesia terkena dampak globalisasi, Indonesia adalah obyek globalisasi. Padahal sejatinya globalisasi itu melibatkan semua warga dunia baik sebagi obyek maupun sebagai subyek. Indonesia adalah salah satu subyek atau pemain globalisasi, Indonesia adalah salah satu pemain kompetisi internasional. Indonesia dengan Strategi Manajemen Pancasila harus berperan aktif sebagai subyek dalam kancah globalisasi karena nenek moyang bangsa Indonesia telah melanglang buana ke manca negara sebagai pemain globalisasi di mulai dari perdagangan dan tentu sisi politik, sosial dan budaya pasti ikut dalam perdagangan itu. Artikel ini membahas tentang analisis Strategi Manajemen Pancasila terhadap globalisasi dengan menggunakan metode kualitatif deskriptif dengan menggabungkan hasil wawancara dan kajian pustaka. Beberapa penelitian menyatakan bahwa Indonesia sebagai obyek terkena dampak globalisasi dan hampir belum ada penelitian yang menyatakan Indonesia sebagai subyek telah berhasil mewarnai globalisasi. Hasil wawancara menemukan Strategi Pancasila berhasil membawa bangsa Indonesia berperan aktif dalam globalisasi sementara informan yang lain menyatakan bahwa masuh diperlukan pendidikan dan pemahaman yang lebih untuk menjalankan Strategi Pancasila dalam berperan aktif di era globalisasi.
\end{abstract}

Kata kunci: Pancasila;Strategi Manajemen;Globalisasi

\section{ABSTRACT}

Pancasila as a national principle of the Republic of Indonesia has detail values as a Strategic Management will continue and well known as Pancasila Strategic Management to guide the daily life of Indonesian. Daily life includes economics sector, politics sector, social and cultures sector. Many peoples still do not understand clearly the role and purpose of Pancasila Strategic Management in globalization. Many people's said and concluded that Indonesia has affected by the globalization, Indonesia as an object of globalization. In fact globalization are involving all people's in this planet although as an object or as a subject. Indonesia is one of the subject or player in the globalization, Indonesia is one of the player of the international competition. Indonesia with Pancasila Strategic Management must very active as a subject or player in the field of globalization because Indonesian ancient had wander the world as a player of globalize trade and for sure the politics, socials and cultures 
involved in those international trade. In this article analysis Pancasila Strategic Management for globalization with interview and literature review method have been discussed. Previous research shown that Indonesia as an object affected by the globalization and almost no research shown that Indonesia as a subject wining and colouring the globalization. While interview result shown that Pancasila Strategic Management is enough to face globalization while another informant said that they still need more training and knowledge about Pancasila strategic management to face globalization.

Keywords: Pancasila;Strategic Management;Globalization

\section{PENDAHULUAN}

Sejak dahulu kala, orang selalu menyukai petualangan dalam perjalanan dari satu tempat ke tempat lain. Dengan berkembangnya zaman dan peradaban manusia, lahirlah kelompok manusia, suku, dan bangsa di dunia. Manusia terus melakukan perjalanannya bertemu dengan kelompok-kelompok manusia, suku-suku dan bangsa-bangsa. Demikianlah kehidupan berlangsung bertahun-tahun lamanya. Maka adalah benar kiranya Tuhan mengajarkan 'ihdinas siratal mustaqim' yang artinya tunjukanlah kami jalan yang lurus (Al-Quran, Surat Al Fatihah ayat 6). Karena kehidupan tidak pernah berhenti berjalan dan Tuhan mengajarkan supaya manusia tetap berjalan di jalan kebenaran atau jalan yang lurus dalam menjalankan kehidupannya serta meminta petunjuk kepada-Nya.

Adalah menjadi sifat manusia untuk saling mempengaruhi dan menguasai satu terhadap yang lainnya. Kelompok satu ingin mempengaruhi dan menguasai kelompok lainnya, suku yang satu ingin mempengaruhi dan menguasai suku lainya, bangsa yang satu ingin mempengaruhi dan menguasai bangsa yang lain. Karena keinginan untuk menguasai itu maka tidak jarang terjadi perselisihan, pertengkaran, perkelahian dan peperangan. Catatan sejarah telah banyak mencatat kisah-kisah peperangan antar suku, bangsa, sebagai buah dari keinginan manusia untuk saling mempengaruhi dan menguasai. Sebenarnya globalisasi yang digaungkan sekarang ini sudah berlangsung sangat lama. Karena manusia memiliki kecenderungan yang kuat untuk hidup bersama dalam satu wilayah (Setiadi, 2002).

Para ahli mendefinisikan globalisasi secara beragam, tetapi pada intinya adalah karena adanya keinginan untuk mempengaruhi dan menguasai antara antara satu kelompok terhadap kelompok lainnya, antara satu suku terhadap suku lainnya, antara bangsa terhadap bangsa lainya. Globalisasi adalah proses yang mencakup sebab, tujuan, dan akibat dari integrasi nasional dan budaya, serta akibat dari aktivitas manusia dan non-manusia. (Al-Rodhan \& Stoudmann, 2006). Yeates dalam (World Economic Forum, 2017) mengatakan bahwa globalisasi dapat didefinisikan sebagai jaringan luas dari koneksi dan proses ekonomi, budaya, sosial dan politik lintas batas.

Terlihat jelas bahwa dengan terjadinya globalisasi akan terjadi integrasi atau penyatuan atau penggabungan budaya, kultur, pola hidup, cara berkomunikasi (berbahasa), tata cara berpakaian dan lainlainya. Sebuah kelompok, suku atau bangsa yang tadinya sudah mempunyai tatanan kehidupan yang homogen sesuai dengan kelompok, suku atau bangsanya sendiri maka dengan datangnya kelompok, suku atau bangsa lain yang berintegrasi akan memberikan dampak dan pengaruh terhadap tata kehidupan kelompok, suku ataupun bangsa yang telah ada sebelumnya. Dampak dan pengaruh terhadap tatanan kehidupan itu apabila tidak di kelola dengan baik akan mengakibatkan adanya perselisihan dan yang paling dahsyat mengakibatkan peperangan. 
Hari berganti, tahun berganti dan abadpun berganti. Di abad 21 ini globalisasi terus menggelora di seluruh belahan dunia yang membawa dampak baik dan buruk. Sebagai negara yang merdeka dan berdaulat sudah tentu Indonesia harus berperan aktif dalam era globalisasi ini. Di masyarakat, di perusahaan sering kita lihat bangsa Indonesia ini kagum dengan para ekspatriat misalnya ekspatriat dari Eropa, Amerika, China, Korea, Arab dan lain sebagainya (FRANCISCO, 2019), demikina juga dalam hal membeli produk banyak bangsa Indonesia yang menyukai produkproduk luar negeri (Setiawan, 2014; Soegiono, 2012). Sepertinya globalisasi internasional seakan-akan sangat mempengaruhi dan mengendalikan kehidupan bangsa Indonesia (Nurhaidah \& Musa, 2015; Yuniarto, 2015). Globalisasi membawa efek negative yangmenyebabkan krisis moral dan karakter kebangsaan (Budiarto, 2020). Di sisi laing lobalisasi juga sangat positif pengaruhnya untuk kehidupan bangsa Indonesia terutama dalam teknologi dan pengembangan ekonomi (Ferdiansyah et al., 2016; Soediro, 2017; Wabaa et al., 2018). Peningkatan pengetahuan sosial dan budaya sangat signifikan dipengaruhi oleh globalisasi (Wabaa et al., 2018) tentu perlu diarahlan dengan baik supaya bangsa hasil positif tersebut bisa terus berkembang terutama melalui pendidikan (Irhandayaningsih, 2012).

Berangkat dari kontradiksi tersebut penulis menemukan pertanyaan yaitu apakah kita sebagai bangsa Indonesia akan mewarnai dunia ini atau kita yang malah di warnai bangsa-bangsa lain. Artikel ini bertujuan untuk menggali dan menganalisis Strategi Manajemen Pancasila terhadap globalisasi secara lebih mendalam, utamanya terhadap kehidupan di Indonesia dan bagaimana peranan Pancasila sebagai dasar negara menghadapi dan mewarnai gelombang besar globalisasi. Penelitian ini diharapkan mendapatkan kebaruan yang lebih cerah terhadap strategi manajemen Pancasila untuk globalisasi sehingga Indonesia bukan hanya sebagai obyek globalisasi tetapi Indonesia sebagai subyek atau pemain yang mewarnai globalisasi akan semakin jelas.

\section{METODE PENELITIAN}

Metode yang digunakan pada penelitian ini adalah pendekatan deskriptif kualitatif. Data diperoleh dari wawancara dengan beberapa informan dari berbagai usia dan kalangan dan hasilnya didokumentasikan, serta diobservasi. Beberapa data juga didapatkan dari hasil studi literatur dengan memaparkan teori dan kajian dari penelitain terdahulu yang sudah dilakukan peneliti-peneliti lain.

\section{HASIL PENELITIAN DAN PEMBAHASAN}

\section{Sejarah Nusantara sebagai pemain globalisasi}

Di kawasan Asia Tenggara globalisasi telah berjalan entah sejak kapan, tetapi ada beberapa catatan sejarah tentang Kerajaan Sriwijaya dan Majapahit kiranya sudah cukup menunjukkan bahwa globalisasi juga sudah terjadi di tingakatan antar negara yang dipelopori oleh Kerajaan Sriwijaya dan Majapahit. Kekuasaan Kerajaan Sriwijaya sebagai hasil dari perdagangan perdagangan internasional di masanya telah menjangkau wilayah wilayah-wilayah Asia Timur, Asia Barat dan Eropa (Pradhani, 2017). Kerajaan besar berikutnya di wilayah Nusantara adalah Kerajaan Majapahit yang menurut Negarakertagama pupuh XIII - XV mempunyai kekuasaan yang luas dan banyak negara-negara di wilayah Asia Tenggara menjalin kerjasama dengan Kerajaan Majapahit seperti: Siam (Thailand), Marutma, Radjapura, Singanagari, Campa (Vietnam), Kamboja, Yawana, Syangka (Haryono, 1997).

Jadi teranglah bahwa kerajaankerajaan yang dulu mashyur dan berjaya di Nusantara ini telah melanglang buana ke beberapa penjuru dunia dan tanpa di 
sadari telah melakukan bahkan memulai globalisasi. Kerajaan-kerajaan Nusantara di masa Sriwijaya dan Majapahit telah mewarnai dunia. Dengan di dukung oleh keahlian maritimnya nenek moyang kita telah aktif mewarnai dunia perdagangan di wilayah Asia dan Eropa.

Hasil wawancara dengan informan 1, 2 dan 3 juga sepakat bahwa sejarah nusantara membuktikan bahwa bangsa Indonesia sebelum kemerdekaan telah berperan aktif dalam globalisasi dunia dengan berdagang ke mancanegara.

Setelah jatuhnya kerajaan-kerajaan besar di Nusantara seperti Kerajaan Sriwijaya dan Kerajaan Majapahit, penjelajah Eropa mulai menapakkan kakinya di Bumi Nusantara di abad 16. Bangsa Portugis mendarat pertama kali di Ambon tahun 1512, selanjutnya di susul oleh Bangsa Spanyol mendarat di Maluku pada tahun 1522 dan Bangsa Belanda mendarat di pelabuhan banten pada tahun 1596 (Absiroh, 2017). Tujuan semula dari penjelajah Eropa itu semata-mata hanyalah hubungan untuk berdagang. Hubungan yang setara antara penjual dan pembeli terjadi layaknya hubungan perdagangan yang wajar, namun karena adanya persaingan dalam dunia perdagangan di antara bangsa-bansa Eropa itu mulailah ada niatan untuk menguasai bumi nusantara yang kaya akan sumber-sumber rempah (Absiroh, 2017). Bangsa-bangsa Eropa itu melihat bahwa bangsa Nusantara ini mudah di pengaruhi dan di kuasai sehingga bangsa-bangsa Eropa itu bercokol sangat lama di bumi Nusantara. Secara tidak terasa globalisasi Barat telah masuk ke bumi Nusantara, segala tatanan kehidupan barat telah masuk dan mewarnai tata kehidupan Nusantara. Banyak sekali pro dan kontra, perselisihan, perkelahian dan pada akhirnya peperangan sebagai akibat dengan masuknya globalisasi Barat itu. Perang Sultan Agung melawan VOC tahun 16281629, Perang Jawa (1741-1743), Perang yang dipimpin Pattimura (1817), Perang di Padri (1821-1837), Perang Pangeran Diponegoro (1925-1830), Perang di daerah
Banjarmasin (1859-1863), Perang di Pulau Bali (1846-1868), Perang Raja Sisingamangaraja XII (1870-1907), Perang Kerajaan Aceh (1873-1906) (Absiroh, 2017). Peperangan-peperangan itu adalah akibat dari adanya globalisasi barat yang ingin terus mencengkeram bumi Nusantara.

Tanggal 6-Juni-1901, di Peneleh, Surabaya lahir bayi laki-laki bernama Kusno, karena sering sakit orang tuanya mengubah namanya menjadi Soekarno (Cahyono, 2016). Soekarno kelak menjadi Proklamator Indonesia dan Presiden pertama Republik Indonesia. Pada pidatonya di Sidang Badan Penyelidik Usaha Persiapan Kemerdekaan Indonesia atau BPUPKI pada hari jum'at, 1-Juni-1945 Soekarno mengatakan bahwa:

Sekarang banyaknya prinsip: Kebangsaan, Internasionalisme, Mufakat, Kesejahteraan dan Ke-Tuhan-an, lima bilangannya. Namanya bukan Panca Dharma, tetapi saya namakan ini dengan petunjuk seorang kita ahli Bahasa namanya ialah PANCASILA. Sila artinya asas atau dasar dan di atas kelima dasar itulah kita mendirikan negara Indonesia, kekal dan abadi (Wikipedia, 2021).

Selanjutnya melalui Keputusan Presiden Nomor 24 tahun 2016 Presiden Joko Widodo menetapkan bahwa 1-Juni1945 sebagai Hari Lahirnya Pancasila (Kemensek RI, 2016). Isi lengkap dari Pancasila adalah:

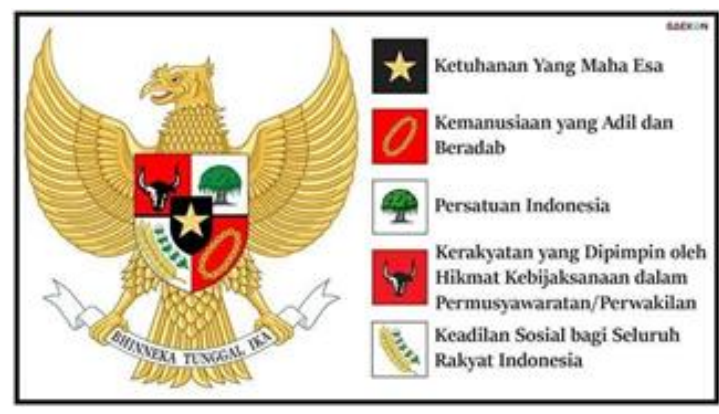

Gambar 1. Pancasila

Pancasila sebagai Dasar Negara Republik Indonesia sudah seharusnya menjadi dasar dalam menyelenggarakan kehidupan berbangsa dan bernegara. Artinya dalam menjalankan kehidupan, bermasyarakat dan bernegara Rakyat dan Pemerintah Indonesia harus selalu berlandaskan Pancasila. 
Globalisasi terus berkembang beriringan dengan kehidupan manusia di seluruh dunia. Indonesia sebagai negara besar mempunyai Dasar Negara yang sangat kokoh bukan saja berpartisipasi dalam globalisasi tetapi berperan aktif, sebagai pelopor, penggerak dan pelaksana globalisasi. Indonesia tentu beserta seluruh rakyat dan pemerintahnya tidak boleh terlindas oleh globalisasi yang dijalankan oleh negara-negara lain di dunia ini. Rakyat dan Pemerintah Indonesia (kita) harus menguasai dan memahami Pancasila dengan baik sehingga bisa berperan aktif dan mengendalikan globalisasi. Kita tidak boleh terpengaruh oleh bangsa lain tetapi malah harus mempengaruhi bangsabangsa lain.

\section{Strategi Sila ke 1 untuk globalisasi}

Seperti di kemukakan di pendahuluan bahwa globalisasi di dasari adanya keinginan manusia untuk mempengaruhi dan menguasai satu sama lainnya. Di mulai dari mempengaruhi antar sesama manusia. Individu mempengaruhi kelompoknya atau sebaliknya, kelompok manusia mempengaruhi kelompok manusia lainnya. Suku bangsa yang satu mempengaruhi suku-suku dan bangsabangsa lainnya. Negara yang satu mempengaruhi negara yang lainya serta menguasainya. Globalisasi adalah sebuah proses yang mencakup sebab, tujuan, dan akibat dari integrasi antar berbagai bangsa dan kultur serta yang lahir dari aktifitas manusia dan non manusia (Al-Rodhan \& Stoudmann, 2006). Apa yang menjadi penyebab terjadinya globalisasi antara lain karena manusia ingin mendapatkan kehidupan yang lebih baik, manusia ingin mengembangkan ekonominya, penghasilannya, kekayaannya, kemasyurannya.

Globalisasi ekonomi merupakan prosess penggabungan atau integrasi ekonomi nasional suatu negara ke dalam ekonomi global (Suprijanto, 2011). Dalam proses integrasi antara kepentingan ekonomi nasional suatu bangsa dan ekonomi global tidak jarang terjadi gesekan-gesekan baik dalam hal ekonomi maupun kemanusiaan dan bahkan dalam hal agama dan menjalankan aktifitas keagamaan. Globalisasi tidak hanya berpengaruh aspek ekonomi, politik, budaya, konsumersime, hedonism, gaya hidup dan lain sebagainya tetapi globalisasi juga mempengaruhi cara berpikir manusia (Hidayat, 2020). Cara perpikir manusia sangat beragam pada masing-masing individu di masing-masing suku bangsa.

Dalam Butir Butir Pancasila, khususnya Sila kesatu yang berbunyi Ketuhanan Yang Maha Esa, dikatakan: (1) Bangsa Indonesia menyatakan keyakinan dan berserah diri kepada Tuhan Yang Maha Esa. (2) Orang Indonesia beriman dan bertakwa kepada Tuhan Yang Maha Esa, sesuai dengan agama dan kepercayaannya masing-masing, serta sesuai dengan prinsip keadilan dan keberadaban. (3) Menumbuhkan sikap hormat dan kerjasama antar umat beragama. (4) Menjalin kehidupan yang rukun diantara sesama bangsa Indonesia yang beriman dan bertakwa kepada Tuhan (5) Agama dan kepercayaan kepada Tuhan Yang Maha Esa adalah hal-hal yang berkaitan dengan hubungan pribadi antara manusia dengan Tuhan Yang Maha Esa. (6) Menumbuh-kembangkan sikap saling menghargai kebebasan beragama. (7) Tidak pernah melakukan pemaksaan untuk memeluk suatu agama dan atau kepercayaan kepada Tuhan Yang Maha Esa kepada orang lain (Kemhan RI, 2014).

Pancasila melalui butir-butirnya memberikan strategi yang sangat jelas dan tegas dalam menghadapi globalisasi, terutama tercantum pada butir ketiga sampai butir ketujuh. Dengan berpedoman pada butir-butir di atas bangsa Indonesia di harapkan tidak mudah tergerus pemikirannya karena adanya arus globalisasi, bangsa Indonesia harus tetap teguh pada agama dan kepercayaan yang di anutnya dan tetap menjalankan kegiatan ibadah sesuai dengan keprcayaan dan 
agamanya masing-masing. Demikian juga apabila bangsa Indonesia melakukan ekspansi keluar negeri baik sebagai pegawai professional atau ekspatriat maupun sebagai bisnisman maka prinsipprinsip kehidupan yang telah di ajarkan pada buti-butir Pancasila Sila kesatu itu juga harus tetap di jalankan di manapun berada.

Hasil wawancara dengan informan 1, 2 dan 3 mereka sepakat bahwa nilai-nilai Pancasila yang secara detail tertuang dalam butir-butir Pancasila sila kesatu sangat cocok dan berfungsi untuk menjaga kerukunan umat beragama dan juga memberikan kebebasan kepada semua bangsa Indonesia untuk memeluk dan beribadah sesuai dengan agamanya masing-masing tanpa adanya paksaan daripihak manapun.

\section{Strategi sila ke-2 untuk globalisasi}

Manusia adalah makhluk sosial secara yang terus menerus ingin berhubungan dengan manusia lainnya terlepas dari suku, ras, bangsa, agama dan lain sebagainya. Dalam interaksi antar manusia internasional sebagai buah dari globalisasi banyak sekali terjadi masalahmasalah positif dan negatif. Para pendatang misalnya duta besar, direktur perusahaan asing, tenaga ahli perusahaan asing dan lain-lainya kerap menghadapi masalah-masalah baik positif maupun negatif ketika menjejakkan kakinya di negara yang baru. Telah menjadi sebuah topik perdebatan semenjak 1900 SM bahwa sangat penting untuk menempatkan para manager di luar negeri selalu mengalami masalah (Aracl, 2015). Demi untuk meningkatkan kinerja perusahaan, banyak sekali perusahaan yang melakukan ekspansi ke luar negeri. Untuk menjalanakn operasionalnya di luar negeri, perusahaan perlu mengirimkan tenaga kerja ahli dari kantor pusat. Ketika seorang ekspatriat di tempatkan di tempat baru, dia harus beradaptasi dengan lingkungan barunya. Tidak jarang terjadi konflik karena sang ekspatriat tidak bisa beradaptasi dengan baik.

Bangsa Indonesia sebagai bagian dari bangsa-bangsa internasional telah mempunyai strategi yang ampuh untuk menghadapi globalisasi ini terutama bagaimana beradaptasi dengan lingkungan baru. Butir-butir Pancasila Sila kedua adalah: (1) Mengakui dan memperlakukan manusia berdasarkan harkat dan martabatnya sebagai ciptaan Tuhan Yang Maha Esa. (2) Mengakui kesetaraan, persamaan hak dan kewajiban manusia, tanpa diskriminasi berdasarkan suku, keturunan, agama, kepercayaan, jenis kelamin, kondisi sosial, warna kulit, dll. (3) Menumbuhkan sikap kasih sayang dan cinta terhadap sesama manusia. (4) Menumbuhkan sikap saling toleransi yang baik kepada sesama manusia. Menumbuhkan sikap tidak sewenangwenang terhadap orang lain. (6) Mematuhi nilai-nilai kemanusiaan. (7) Suka berpartisipasi dalam kegiatan kemanusiaan. (8) Berani membela kebenaran dan keadilan (9) Rakyat Indonesia merasa menjadi bagian dari seluruh umat manusia. (10) Menumbuhkan sikap hormat dan kerjasama yang baik dengan lain bangsa dalam kesetaraan sebagai manusia ciptaan Tuhan Yang Maha Esa (Kemhan RI, 2014).

Terlihat jelas betapa pendiri negara kesatuan Republik Indonesia ini telah menyiapkan strategi untuk ikut aktif berperan dalam globalisasi dan bagaimana bangsa Indonesia ini tidak terlindas oleh globalisasi. Dari Pancasila sila ke-2 manusia Indonesia di ajarkan dan diberi strategi untuk berperan aktif diarena pergaulan dunia dengan memperlakukan manusia sesuai dengan harkat dan martabatnya, manusia Indonesia harus berperilaku sama dan sederajat dengan semua manusia di dunia, tidak menganggap bangsa lain lebih tinggi derajat dari bangsa Indonesia atau sebaliknya tetapi bangsa Indonesia adalah sama dan sejajar dengan bangsa-bangsa lain di dunia. Manusia Indonesia juga harus saling mencintai sesame manusia, 
saling tenggang rasa, tidak semena-mena, menjunjung tinggi nilai-nilai kemanusiaan serta gemar melakukan kegiatan kemanusiaan. Manusia Indonesia harus berani membela kebenaran dan keadilan serta manusia Indonesia harus berperan aktif dalam pergaulan dunia dengan memegang teguh kesetaraan derajat sebagai makhluk Tuhan di muka bumi.

Butir-butir Pancasila sila kedua tersebut juga sangat berguna untuk menjalankan strategi di segala bidang baik ekonomi, sosial, pendidikan, kebudayaan dan lain sebagainya di dalam negeri. Manusia Indonesia harus bisa menempatkan dirinya dengan baik dan bergaul bersama sesama bangsa Indonesia maupun dengan bangsa asing atau ekspatriat yang ada di Indonesia. Tidak perlu meninggikan derajat para orang asing atau ekspatriat tetapi juga tidak merendahkan mereka. Pancasila sila kedua mengajarkan kesetaraan derajat antar sesama manusia.

Hasil wawancara dengan informan 1, 2 dan 3 menemukan hasil yang berbeda. Dalam menghadapi era globalisasi informan 1 sepakat bahwa butir-butir Pancasila sila kedua sudah sangat cukup untuk mengantarkan bangsa Indonesia bergaul sejajar dengan bangsa-bangsa lain. Keseluruhan butir-butir Pancasila sila kedua sangat jelas memberikan strategi kepada seluruh rakyat Indonesia untuk bertidank sejajar, saling hormat menghormati dengan bangsa lain. Namun informan 2 dan 3 menekankan bahwa diperlukan pemahaman yang lebih mendalam bagi generasi milenial untuk mengerti dan memahami secara medalam terhadap makna butir-butir sila kedua untuk globalisasi. Informan 2 dan 3 sepakat bahwa sebagian generasi muda terkagumkagum dengan kemajuan negara lain dan menganggap bangsa Indonesia ketinggan dari bangsa asing, mereka kurang begitu yakin akan kesejajaran bangsa Indonesia dengan bangsa lain.

\section{Strategi sila ke-3 untuk globalisasi}

Globalisasi melibatkan penggabungan ekonomi, transfer kebijakan yang tidak mengenal batas, transfer ilmu dan pengetahuan, guncangan-guncangan dalam kehidupan masyarakat, munculnya hubungan antara pendatang dan tempatan dan juga wacana kekuasaan. Kesemua itu adalah konsep globalisasi sebagai tujuan utama globalisasi yaitu pembentukan pasar global yang bebas dari kendali sosiopolitik (Al-Rodhan \& Stoudmann, 2006). Globalisasi di sektor ekonomi telah melahirkan adanya perdagangan bebas antar negara. Perdagangan bebas di tunjukan dengan adanya situasi arus lalu lintas barang, jasa dan manusia dari satu negara ke negara lainnya tidak mengalami hambatan yang berarti (Nurhayati, 2015). Indonesia sebagai salah satu pemain globalisasi tentu akan menghadapi situasi seperti itu yang tentu bisa menimbulkan peluang dan ancaman bagi bangsa Indonesia.

Sila ketiga Pancasila memberikan strategi menghadapi globalisasi, yang terangkum sebagai berikut (1) Bangsa Indonesia mempunyai kemampuan untuk meletakkan persatuan, kesatuan, kepentingan dan keamanan bangsa dan negara sebagai kepentingan bersama di atas kepentingan individu maupun kepentingan kelompok. (2) Sanggup serta iklas berkorban untuk kepentingan negara dan bangsa bilamana diperlukan. (3) Menumbuh-kembangkan rasa cinta tanah air dan bangsa. (4) Menumbuhkembangkan kebanggaan nasional dan rasa cinta tanah air Indonesia. (5) Memelihara ketertiban dunia yang berdasarkan persamaan, kemerdekaan, perdamaian abadi, serta keadilan sosial. (6) Membangun persatuan Indonesia berdasarkan Bhineka Tunggal Ika. (7) Memajukan kerjasama antar-bangsa untuk persatuan dan kesatuan negara (Kemhan RI, 2014).

Globalisasi telah melahirkan peluang dan ancaman baik positif maupun negatif, para pendiri Negara Kesatuan Republik 
Indonesia telah memberikan strategi bagaimana berperan aktif dalam berperan aktif untuk globalisasi (Al-Rodhan \& Stoudmann, 2006; Nurhayati, 2015). Pada ketujuh butir-butir Pancasila sila ke-3 tersebut di atas jelas sekali disebutkan bagaimana strategi bangsa Indonesia untuk berperan aktif menjadi pemain globalisasi dengan tetap berpegang teguh pada Persatuan Indonesia. Dalam masyarakat Indoensia cukup banyak terjadi kekhawatiran menghadapi globalisasi dan seakan-akan Indonesia hanya sebagi obyek globalisasi. Bangsa Indonesia secara keseluruhan harus merubah pola pikir atau mind set yang sebagian bangsa Indonesia menganggap bangsa asing (luar negeri) itu lebih tinggi martabatnya dari bangsa Indonesia. Bangsa Indonesia harus bisa mewarnai dunia dalam kancah globalisasi, bangsa Indonesia tidak boleh hanya beranggapan bahwa bangsa asing lebih tinggi martabatnya. Karena hanya dengan merubah pola pikir itulah maka bangsa Indonesia ini akan mampu berperan aktif dalam kancah globalisasi.

Terdapat perbedaan hasil wawancara antara informan 1, 2 dan 3. Informan 1 mengatakan bahwa keseluruhan butirbutir sila ketiga Pancasila sudah sangat cukup memberikan bekal kepada bangsa Indonesia untuk berperan aktif dalam pergaulan globalisasi dunia dengan tetap mempunyai jati diri sebagai bangsa Indonesia. Tetapi informan 2 dan 3 mengatakan bahwa generasi muda mempunyai cara sendiri untuk menjaga persatuan dan kesatuan bangsa dan mereka tidak memahami cara menjaga persatuan dan kesatuan bangsa Indonesia berdasarkan Pancasila khususnya yang termaktub dalam butir-butir sila ketiga. Informan 2 dan 3 menekankan bahwa pemahaman mereka tentang Pancasila sangat kurang sehingga tidak terlalu memahami peranan Pancasila untuk globalisasi meskipun telah tertuang dalam butir-butir Pancasila kususnya sila ketiga secara jelas.

\section{Strategi sila ke-4 untuk globalisasi}

Pancasila sila keempat berbunyi 'Kerakyatan yang dipimpin oleh hikmat dalam permusyawaratan perwakilan'. Presiden Sukarno pada tanggal 30September-1960 dalam pidatonya di depan sidang umum PBB menyatakan bahwa esensi dari sila keempat Pancasila itu adalah demokrasi. Di era modern ini demokrasi di anggap sebagai sistem pemerintahan yang sangat baik karena inti dari demokrasi adalah keterlibatan rakyat dalam pengambilan keputusannya (Winarno, 2014). Bagi proses kelangsungan demokrasi, globalisasi akan memberikan dua kemungkinan sekaligus. Di satu sisi globalisasi bisa mendorong proses demokratisasi kea rah yang baik dan di sisi lain globalisasi bisa menciptakan krisis terhadap pelaksanaan demokrasi itu sendiri (Winarno, 2008).

Pada penelitian lain menemukan bahwa proses-proses globalisasi yang terjadi di tingkatan global berpengaruh positif terhadap proses-proses demokratisasi di tingkat nasional. Pengaruh positif globalisasi terhadap demokratisasi terlihat antara lain dengan mulai terkiskisnya dominasi kekuasaan negara untuk bergerak secara otonom (Susanto, 2000).

Dalam butir-butirPancasila sila keempat , pendiri bangsa Indonesia memberikan strategi menghadapi globalisasi, dengan tetap mengedepankan prinsip-prinsip demokrasi dengan cara: (1) Sebagai warga negara dan warga sosial, setiap orang Indonesia memiliki kedudukan, hak dan kewajiban yang sama. (2) Warga negara Indonesi tidak diijinkan memaksakan kehendak kepada sesama warga negara maupun warga dunia. (3) Selalu mengambil keputusan berdasarkan musyawarah dan mufakat demi kepentingan hidup bersama-sama (4) Dalam menjalankan musyawarah selalu berlandaskan kekeluargaan (5) Menghormati dan membela semua keputusan yang disengaja. (6) Menerima dan melaksanakan 
hasil keputusan musyawarah dengan itikad baik dan rasa tanggung jawab. (7) Dalam melakukan musyawarah tidak menonjolkan kepentingan pribadi dan golongan melainkan selalu menempatkan kepentingan bersama yang paling utama. (8) Akal sehat dan hati nurani selalu menjadi pijakan pokok dalam bermusyawarah (9) Keputusan yang diambil tidak harus bisa dipertanggungjawabkan secara moral kelak dihadapan Tuhan Yang Maha Esa serta menjaga harkat dan martabat manusia, menjunjung tinggi nilai-nilai kebenaran dan keadilan meninggikan persatuan dan kesatuan untuk kebaikan bersama. (10) Mendelegasikan kepercayaan kepada wakil rakyat untuk melakukan permusyawaratan demi kemaslahatan rakyat Indonesia (Kemhan RI, 2014).

Jadi dengan memahami dan mengamalkan atau menjalankan butirbutir Pancasila sila keempat tersebut, maka bangsa Indonesia dalam hal ini adalah rakyat dan pemerintah Indonesia akan dapat berperan aktif dalam globalisasi dengan tetap mengedepankan prinsipprinsip demokrasi. Bangsa Indonesia tidak hanya sebagai obyek globalisasi tetapi bangsa Indonesia juga menjadi subjek globalisasi. Baik sebagai obyek maupun sebagai subyek globalisasi, kesepuluh butir-butir Pancasila sila keempat tersebut sangat tepat untuk dijalan sebagai strategi untuk berperan aktif dalam kancah globalisasi.

Hasil wawancara dengan informan 1, 2 dan 3 sepakat bahwa musyawarah dan mufakat adalah salah satu strategi demokrasi. Ketiga informan juga sepakat bahwa butir-butir Pancasila sila keempat adalah pengejowantahan dari demokrasi. Generasi muda sangat senang sekali apabila suara mereka didengarkan dan diakomodasi. Generasi muda juga memahami bahwa masing-masing rakyat Indonesia mempunyai pendapat yang berbeda-beda dan generasi muda juga sepakat untuk menjalankan keputusan yang telah diambil dalam keputusan rapat bersama.

\section{Strategi sila ke-5 untuk globalisasi}

Tujuan daripada kehidupan manusia dalam bermasayarakat dan bernegara adalah untuk mencapai keadilan sosial, berdiri sama tinggi, sederajat dan saling hormat menghormati. Namun tujuan mulia itu tidak mudah untuk di capai. Beberapa peneliti mengatakan bahwa keadilan sosial tidak tercapai karena adanya pengaruh globalisasi. Partisipasi global menyebabkan munculnya ketimpangan global. Singkatnya, manfaat mengintegrasikan si kaya berbanding lurus dengan si miskin, dan globalisasi justru akan membuat si miskin semakin miskin secara absolut (Hutagalung, 2016). Perkembangan pembangunan ekonomi Indonesia yang telah dijalankan sejak beberapa dasawarsa menimbulkan semakin meningkatnya wilayah dan permukiman miskin sedangkan dibagian lain ada sebagian orang yang menguasai perekonomian negara secara besar (Syarbaini, 2017).

Pancasila sila kelima memberikan strategi bagaimana kiat-kiat untuk menjalankan kehidupan guna mencapai keadilan sosial bagi seluruh rakyat Indonesia. Butir-butir Pancasila sila ke-5 sebagai bentuk strategi untuk globalisasi adalah sebagai berikut: Mengembangkan perilaku luhur yang mencerminkan sikap dan suasana kekeluargaan dan gotong royong. (2) Menumbuhkan sikap adil terhadap orang lain. (3) Menjaga keseimbangan antara hak dan kewajiban. (4) Menghormati hak warga masyarakat lain. (5) Senang dan gembira membantu orang lain agar supaya orang yang dalam kesulitan bisa mandiri. (6) Tidak menggunakan hak milik untuk usaha-usaha memeras orang lain. (7) Tidak berperilkau dan menggunakan hak milik sendiri untuk gaya hidup yang berlebihan dan bermewah-mewahan. (8) Tidak menggunakan hak milik untuk hal-hal yang berbenturan atau merusak 
kepentingan umum. (9) Rajin dan suka bekerja dengan keras untuk mencapai tujuan hidupnya. (10) Bangsa Indonesia suka menghargai karya orang lain yang bermanfaat bagi kemajuan dan kemakmuran semua orang. (11) Bangsa Indonesia senang dan gembira melakukan kegiatan untuk mencapai kemajuan yang seimbang dan berkeadilan sosial (Kemhan RI, 2014).

Sangat jelas sekali dari uraian kesebelas butir-butir Pancasila sila kelima tersebut sebagai strategi bangsa Indonesia dalam menghadapi globalisasi dan tetap fokus untuk mencapai keadilan sosial. Globalisasi bukanlah ancaman, bukanlah hambatan untuk mencapai keadilan sosial bagi seluruh rakyat Indonesia karena para 'founding father' telah memberikan strategi yang sangat baik untuk berperan aktif dalam kancah pergaulan dunia.

Hasil wawancara dengan informan 1 menyatakan sangat optimis bahwa dengan menjalankan kehidupan berdasarkan butir-butir Pancasila sila kelima maka keadilan dan kemakmuran untuk selurh rakyat Indonesia akan tercapai. Tetapi informan 2 dan 3 mengatakan bahwa tidak serta merta hanya dengan menjalankan butir-butir Pancasila sila kelima maka kemakmura akan tercapai. Informan 2 dan 3 sepakat bahwa untuk sukses maka harus bekerja keras, namun demikian informan 2 dan 3 kurang memahami bahwa kerja keras adalah bagian dari sila kelima. Sekalilagi informan 2 dan 3 menyatakan bahwa pemahaman mereka tentang Pancasila masih sangat kurang meskipun mereka sudah lulus dari perguruan tinggi.

\section{KESIMPULAN}

Globalisasi adalah sebuah keniscayaan. Indonesia yang di dahului oleh kerajaan-kerajaan Nusantara telah berperan aktif dalam kancah globalisasi. Indonesia tidak hanya sebagai obyek dalam arus globalisasi tetapi Indonesia juga sebagai SUBYEK dalam arus besar globalisasi. Pancasila mempunyai butirbutir atau lebih tepatnya strategi manajemen dalam menjalankan kehidupan untuk berperan aktif di dalam kancah globalisasi. Strategi Pancasila atau Strategi Manajemen Pancasila untuk sangat perlu untuk di pahami oleh seluruh komponen bangsa Indonesia agar bisa menjadi pemain sukses dalam kancah globalisasi.

Para informan sepakat bahwa bangsa Indonesia harus menang atau paling tidak sejajar dengan bangsa-bangsa lain di dunia. Sebagin informan memerlukan pendidikan dan pemahaman yang lebih untuk mengerti dan memahami kegunaan nilai-nilai luhur Pancasila dalam praktek kehidupan sehari-hari baik berhubungan dengan pekerjaan maupun untuk interaksi dengan masyarakat sekitarnya.

Penelitian masih terbatas pada pembahasan-pembahasan hasil penelitian masa lalu dan wawancara dengan beberapa informan, tentu sangat terbuka kesempatan untuk penelitian selanjutnya. Penelitian lanjutan diharapkan lebih spesifik tentang peranan Strategi Manajemen Pancasila pada perusahaanperusahaan modal dalam negeri maupun perusahaan-perusahaan modal asing, peranan Strategi Manajemen Pancasila dalam rangka ekspansi perusahaan nasional ke luar negeri dan sebagainya.

\section{DAFTAR PUSTAKA}

Absiroh, U. (2017). Understanding of History 350 Years Indonesia Colonized By Dutch. Jurnal Online Mahasiswa (JOM) Fakultas Keguruan Dan Ilmu Pendidikan (FKIP) Universitas Riau, 1,1-15.

Al-Rodhan, N., \& Stoudmann, G. (2006). Definitions of globalization: A comprehensive overview and a proposed definition. Occasional Papers, Geneva Centre ..., 1-21. 
Arac1, M. (2015). The Barriers to Increasing the Productivity in Expatriate Management: Examples in the World and Turkey. Procedia - Social and Behavioral Sciences, 195, 993-1002. https:// doi.org/10.1016/j.sbspro.2015.06.326

Budiarto, G. (2020). Indonesia dalam Pusaran Globalisasi dan Pengaruhnya Terhadap Krisis Moral dan Karakter. Pamator Journal, 13(1), 50-56. https:/ / doi.org/10.21107/pamator.v13i1.6912

Cahyono, Y. D. (2016). Pembentukan Karakter Bangsa Ala Sukarno dan Suharto dalam Perspektif Sejarah Pemerintahan di Indonesia. 20(1).

Ferdiansyah, Tin, S., \& Anthonius. (2016). Globalisasi Ekonomi, Integrasi Ekonomi Global, Dinamika Pasar Modal \& Kebutuhan Standar Akuntansi Internasional. Jurnal Akuntansi, 8(1), 119-130.

FRANCISCO, Y. (2019). Analisis Kebijakan Kompensasi Ekspatriat Pada Perusahaan Multinasional. Universitas Sumatera Utara.

Haryono, T. (1997). Kerajaan Majapahit:Masa Sri Rajasanagara Sampai Rajaswadhanna. Jurnal Humaniora, $V$, 107-113.

Hidayat, R. (2020). Dunia dan Din (Agama) Di Tengah Arus Globalisasi. JSA, 2507(June), 1-9.

Hutagalung, D. (2016). ANTARA HASRAT DAN JERAT GLOBALISASI - NEOLIBERAL. May 2012. https:// doi.org/10.13140/RG.2.1.5170.7926

Irhandayaningsih, A. (2012). Peranan Pancasila Dalam Menumbuhkan Kesadaran Nasionalisme Generasi Muda Di Era Global. Humanika, 16(9), 54-67.

Kemensek RI. (2016). Kepres No 24 Tahun 2016. Kemensek RI.

Kemhan RI. (2014). 45 Butir Pedoman Penghayatan dan Pengamalan Pancasila. Dirjen Perencanaan Pertahanan. https://www.kemhan.go.id/renhan/2014/11/20/45-butir-pedomanpenghayatan-dan-pengamalan-pancasila.html

Nurhaidah, N., \& Musa, m I. (2015). Dampak Pengaruh Globalisasi Bagi Kehidupan Bangsa Indonesia. Jurnal Pesona Dasar, 3(3), 1-14.

Nurhayati, D. (2015). Strategi Indonesia dalam Menghadapi Tantangan Global Dibidang Ekonomi. Jurnal Heritage, 3(1).

Pradhani, S. I. (2017). Sejarah hukum maritim kerajaan Sriwijaya dan Majapahit dalam hukum Indonesia kini (The history of Sriwijaya and Majapahit maritime laws in Indonesia law today). Lembaran Sejarah, 13(2), 186-203.

Setiadi, E. (2002). Pengaruh Globalisasi Terhadap Substansi Hukum dan Penegakan Hukum. Mimbar, XVIII(4), 443-456.

Setiawan, E. (2014). Analisis Sikap Konsumen Terhadap Produk Fashion Lokal Dan Impor. Jurnal Economia, 10(1), 38-47. https://doi.org/10.21831/economia.v10i1.4093

Soediro, S. (2017). Hubungan Hukum dan Globalisasi: Upaya Mengantisipasi Dampak Negatifnya. Jurnal Kosmik Hukum, 17(1).

Soegiono, F. (2012). Impor vs Lokal: Studi Kasus Tentang Keputusan Membeli Makanan Kemasan. Jurnal Ilmiah Mahasiswa Universitas Surabaya, 1(1).

Suprijanto, A. (2011). Dampak globalisasi ekonomi terhadap perekonomian Indonesia. Jurnal Imiah CIVIS, I(2), 100-119.

Susanto, J. (2000). Kajian Teoritik Tentang Pengaruh Globalisasi. 2, 59-72.

Syarbaini, S. (2017). Pancasila Sebagai Paradigma Pembangunan Tinjauan Implementasi Pancasila Dalam Sistem Ekonomi. 14, 126-139.

Wabaa, M., Laloma, A., \& Londa, V. Y. (2018). PENGARUH GLOBALISASI INFORMASI TERHADAP KEHIDUPAN SOSIAL BUDAYA GENERASI MUDA ( SUATU STUDI DI 
SMA NEGERI 1 BEO KABUPATEN KEPULAUAN TALAUD ) MARTHA. Journal of Chemical Information and Modeling, 53(9), 1689-1699.

Wikipedia. (2021). Sukarno. Wikipedia. https://en.wikipedia.org/wiki/Sukarno

Winarno, B. (2008). Globalisasi dan Masa Depan Demokrasi. Jurnal Global Dan Strategis, 3(2), 123-141.

World Economic Forum. (2017). What is Globalisation Anyway? World Economic Forum, April. https:// doi.org/10.13140/RG.2.2.16793.93288

Yuniarto, P. R. (2015). Masalah Globalisasi di Indonesia: Antar Kepentingan, Kebijakan dan Tantangan. Jurnal Kajian Wilayah, 5(1), 67-95. 